\title{
MANAJEMEN PENDIDIKAN AGAMA KRISTEN MELALUI PELAYANAN PENGGEMBALAAN DALAM KELOMPOK SEL
}

\section{CHRISTIAN RELIGIOUS EDUCATION MANAGEMENT THROUGH PASTORAL SERVICES IN CELL GROUPS}

\author{
Imron Widjaja ${ }^{1}$, Bobby Kurnia Putrawan, ${ }^{2}$ Hengki Wijaya ${ }^{3}$ \\ ${ }^{1}$ Sekolah Tinggi Teologi Periago Jl. Bambu Ori Raya No. 5 Jakarta 13430 \\ ${ }^{2}$ Sekolah Tinggi Teologi Moriah, Jl. CBD Barat Raya Kav.1, Tangerang, Banten 15810 \\ ${ }^{3}$ Sekolah Tinggi Filsafat Jaffray Makassar, Jl. Gunung Merapi 103 Makassar, Sulawesi Selatan \\ email: bkputrawan@gmail.com
}

Naskah Diterima: 18 November 2019; Direvisi: 25 Februari 2020; Disetujui: 12 Agustus 2020

\begin{abstract}
Christian Religious Education Management is carried out in smaller groups. The church is a broader community. Through pastoral care, the implementation of Christian Religious Education is expected to have a real impact on church members. Cell groups are small groups that can be optimized to achieve the goals of Christian Religious Education. This research uses quantitative research methodology with data analysis using the Rating Scale using 87 respondents of GBI Graha Pena members who responded to the statement given. The results showed the respondents understood the management of Christian Religious Education in pastoral care. Still, it needed the encouragement of leaders to make disciples so that they could carry out pastoral care-they need for members for pastoral care and Cell Group members to be more involved in ministry. Students learn to become cell group leaders by doing what they already understand to serve others.
\end{abstract}

Keywords: Cell group; Education; Management; Pastoral; Religion

\begin{abstract}
Abstrak
Manajemen Pendidikan Agama Kristen dilaksanakan dalam kelompok yang lebih kecil. Gereja adalah komunitas yang lebih besar. Pelaksanaan Pendidikan Agama Kristen melalui pelayanan pastoral diharapkan dapat memberikan dampak nyata bagi anggota gereja. Kelompok sel adalah kelompok kecil yang dapat dioptimalkan untuk mencapai tujuan Pendidikan Agama Kristen. Penelitian ini menggunakan metodologi penelitian kuantitatif dengan analisis data menggunakan Rating Scale dengan menggunakan 87 responden anggota GBI Graha Pena yang memberikan respons atas pernyataan yang diberikan. Hasil penelitian menunjukkan responden memahami manajemen Pendidikan Agama Kristen dalam pelayanan pastoral, namun perlu dorongan pemimpin untuk memuridkan anggota supaya mampu melaksanakan pelayanan pastoral. Kebutuhan anggota akan pelayanan pastoral dan anggota kelompok sel untuk lebih banyak terlibat dalam pelayanan. Murid belajar untuk menjadi pemimpin kelompok sel dengan melakukan apa yang mereka sudah mengerti untuk melayani orang lain.
\end{abstract}

Kata Kunci: Agama; Kelompok sel; Pendidikan; Penggembalaan 


\section{PENDAHULUAN}

Manajemen pendidikan tidak hanya dibutuhkan dalam lembaga pendidikan, tetapi juga dibutuhkan dalam kelembagaan gereja. Manajemen Pendidikan Agama Kristen (PAK) bertujuan untuk membangun jemaat-Nya sebagai pribadi-pribadi yang direfleksikan dalam khotbah Tuhan Yesus di bukit. Khotbah Tuhan Yesus di bukit adalah pengajaran Tuhan Yesus melalui pelayanan khotbah di bukit. Wijaya \& Harimisa (2015) memaparkan ucapan bahagia berdasarkan Matius 5:3-12 juga menjanjikan Kerajaan Allah itu sendiri melalui berkat, yang Yesus beritakan dalam pengajaran-Nya, bukan saja berkat masa depan, tetapi juga berkat masa kini bagi mereka yang miskin, berduka, lemah lembut, murah hati, lapar dan haus, berhati suci, suka berdamai dan yang siap menderita untuk kehendak Allah. Patandean \& Hermanto, (2019) mengungkapkan "Semua pengajaran, nasihat dan jawaban yang diberikan atas pertanyaan orang-orang secara pribadi maupun kelompok orang, bersesuaian dengan pengajaran-Nya melalui khotbah di bukit." Hal yang menarik yang dilakukan Yesus dalam pengelolaan pengajarannya adalah mengajar agama yang tidak dibatasi oleh tempat bahkan bukit pun menjadi tempat untuk mengajarkan nilai-nilai agama.

Sinlae (2019) mengatakan bahwa Yesus tidak memerlukan sekolah atau gedung tertentu, setiap keadaan dan pertemuan selalu di gunakan untuk menyampaikan firman Allah. Dalam Pengajaran-Nya, Tuhan Yesus mempunyai tujuan untuk membahas berbagai topik tentang keagamaan dan kesusilaan secara ilmiah atau teori dan melayani setiap orang yang datang kepada-Nya. Nainggolan, (2019) berpendapat bahwa tujuan manajemen PAK adalah memberdayakan pengetahuan, sikap, dan keterampilan jemaat sebagai pembelajarpembelajar firman Tuhan yang aktif dan setia, yang mendasari praktik nyata pelayanan diakonia (penggembalaan) dalam kehidupan jemaat.

Dalam pelayanan penggembalaan Yesus melalui khotbah di bukit itu mengungkapkan dua perkataan yang menyingkapkan tantangan terhadap dunia modern, yaitu ungkapan kebudayaan tandingan dan kebudayaan alternatif (Stott, 1999). Khotbah itu mengajarkan tentang Kerajaan Allah yang sudah lama dijanjikan dalam Perjanjian Lama. Sejak itu Yesus memulai melakukan tugas pelayanan penggembalaan-Nya. Ia berkeliling di seluruh Galilea, Ia mengajar dalam rumahrumah ibadat dan memberitakan Injil Kerajaan Allah. Khotbah di bukit melukiskan tentang PAK yang dikelola sedemikian rupa untuk menyampaikan pengajaran ucapan bahagia Yesus.

Dalam pandangan penulis kunci khotbah di Bukit, "Janganlah kamu seperti mereka" (Mat. 6:8). Perintah Tuhan ini mengajarkan perubahan sikap hidup orang-orang yang sudah percaya pada Tuhan Yesus sebagai Tuhan dan Juru selamat, di sini penulis memandang pentingnya Pendidikan dalam pelayanan penggembalaan yang dilakukan di kelompok sel dengan tujuan akhir pendewasaan iman anggota jemaat yang mengikuti kelompok sel yang diadakan oleh GBI Graha Pena di berbagai wilayah.

Pelayanan penggembalaan tidak sematamata perkunjungan ke rumah jemaat tetapi juga mengedepankan pengajaran yang teguh. Hal ini membutuhkan wadah untuk berkumpul untuk berdiskusi, belajar, dan berbagi dalam suatu komunitas yang lebih kecil di luar gereja. Pengamatan penulis di GBI Graha Pena menunjukkan adanya usaha mengembangkan manajemen PAK melalui pelayanan penggembalaan dalam kelompok sel melalui pendekatan dengan Persekutuan Rumah Tangga/Komunitas Sel (PRT/Komsel). Kelompok-kelompok sel tersebut merupakan pelayanan gereja untuk meningkatkan pemahaman anggota tentang PAK melalui pelayanan penggembalaan yang mengarah kepada pengetahuan, pemahaman dan pelaksanaan PAK dalam kehidupan beragama. Dengan demikian tujuan pembelajaran PAK dapat tercapai yaitu memberikan pertumbuhan iman anggota jemaat.

Pelayanan penggembalaan dilakukan bukan oleh gembala sebagai pemimpin tetapi juga jemaat sebagai pelayan Tuhan. Oleh karena itu, gembala dan anggotanya perlu melakukan pelayanan penggembalaan yang optimal. Widiyanto \& Susanto, (2020) mengungkapkan pelayanan kunjungan pastoral 
akan mendekatkan gembala dengan jemaat yang dilayaninya, membuat pelayanan penggembalaan menjadi efektif, sehingga berdampak pada pertumbuhan rohani jemaat. Selanjutnya Widiyanto \& Susanto, (2020) berdasarkan hasil analisis menunjukkan bahwa terdapat pengaruh pelayanan kunjungan pastoral terhadap pertumbuhan rohani jemaat. Semakin baik dan intens pelayanan kunjungan pastoral yang dilakukan gembala jemaat maupun Badan Pengurus Jemaat atau Majelis Gereja akan berdampak pada peningkatan pertumbuhan rohani jemaat.

Perkataan firman Tuhan "Gembalakanlah kawanan domba Allah yang ada padamu, jangan dengan paksa, tetapi dengan sukarela sesuai dengan kehendak Allah, dan jangan karena mau mencari keuntungan, tetapi dengan pengabdian diri. Janganlah kamu berbuat seolah-olah kamu mau memerintah atas mereka yang dipercayakan kepadamu, tetapi hendaklah kamu menjadi teladan bagi kawanan domba itu" (1Ptr. 5:2-3). Channing, (2002) menyatakan bahwa pelayanan penggembalaan adalah panggilan Bersama umat Tuhan untuk melayani.

Pelayanan penggembalaan adalah pelayanan pengabdian dan bukan untuk mencari keuntungan. Untuk itu, pelayanan ini dimulai dari pemimpin memberikan teladan kepada umat Tuhan dalam melayani. Kepemimpinan hamba adalah kepemimpinan yang tepat untuk melayani dan memberikan teladan dalam penggembalaan (Ronda, 2011; Patricia \& Susanti, 2019). Pelayanan penggembalaan juga dikenal sebagai pelayanan pastoral. Pelayanan pastoral memiliki ruang lingkup yang luas mulai dari perkunjungan, mendoakan orang sakit dan yang terkena okultisme (Juld \& Enoh, 2013), dan memberikan pelayanan konseling, memberikan pengajaran PAK sebagai dasar iman yang teguh (Ronda, 2013).

Ada dua hal yang tidak biasa dilakukan dalam kelompok sel adalah menerapkan pelayanan penggembalaan dalam kelompok sel dan manajemen Pendidikan dalam penggembalaan. Tulisan ini memadukan manajemen Pendidikan melalui pelayanan penggembalaan di dalam kelompok sel. Penulis meyakini bahwa menerapkan manajemen Pendidikan memberi dampak kepada pelayanan penggembalaan dalam kelompok sel.

Manajemen Pendidikan dalam beberapa penelitian juga digunakan dalam mengelola trauma (Kleber et al., 2013), mengelola perilaku dalam kelas (Hoff \& DuPaul, 1998), dalam manajemen kepemimpinan (Başarı et al., 2017; Bekker, 2009; Bush, 2002; Patricia \& Susanti, 2019). Hal yang sama juga dibutuhkan untuk pelayanan gereja dimana peran manajemen Pendidikan dalam pelayanan penggembalaan menjadi urgen dan memberikan dampak bila diterapkan dalam kelompok sel sebagai komunitas kelompok kecil dari gereja.

Rumusan masalah penelitian ini adalah bagaimana pemahaman jemaat tentang arti dan makna manajemen Pendidikan dalam pelayanan penggembalaan? Bagaimana pelaksanaan manajemen PAK melalui pelayanan penggembalaan dalam kelompok sel? Bagaimana respons jemaat terhadap pelaksanaan manajemen PAK melalui pelayanan penggembalaan dalam kelompok sel? Bagaimana keterlibatan jemaat dalam pelayanan penggembalaan?.

\section{KAJIAN TEORI}

\section{Manajemen Pendidikan}

Definisi manajemen pendidikan adalah manajemen yang diterapkan dalam pengembangan pendidikan (Muhaimin, 2015). Ilmu manajemen berhubungan secara langsung dengan organisasi yang di dalamnya terdapat seni membangun strategi pengambilan keputusan (Hikmat, 2009). Manajemen PAK berarti seni dan ilmu mengelola sumber daya Pendidikan Kristen untuk mencapai tujuan Pendidikan Kristen yang efektif dan efisien. Untuk mencapai tujuan yang efektif dan efisien maka perlu ada evaluasi dalam pelaksanaan manajemen pendidikan. Fadhli, (2017) mengungkapkan evaluasi proses pendidikan yang meningkatkan kebutuhan untuk mencapai dan proses mengembangkan bakat (peserta didik), dan pada saat yang sama memenuhi standar akuntabilitas yang ditetapkan stakeholder yang terlibat untuk proses atau output dari proses pendidikan. 
Bagaimana menyikapi peluang dalam manajemen pendidikan? Kusuma (2006) mengungkapkan dalam tulisannya beberapa komitmen.

(1) menekankan pada standar kendali mutu dengan menetapkan strategistrategi dalam mencapai target yang telah ditetapkan dan konsisten melakukan perbaikan berkelanjutan, (2) memberdayakan seluruh sumber yang ada baik sumber daya manusia maupun sumber dana yang lain, (3) meningkatkan profesionalitas kerja, (4) mengadakan evaluasi yang berkesinambungan baik evaluasi formatif maupun evaluasi sumatif, (5) mengadakan penelitian dan pengkajian dalam pengembangan program, (6) mengikuti dinamika perubahan zamannya dan selalu melakukan inovasi-inovasi dalam segala bidang.

Manajemen PAK dalam pelayanan penggembalaan dievaluasi materi yang diajarkan, sumber daya manusia pelaksana pelayanan penggembalaan dalam Kelompok Sel. Dasar Alkitab tentang PAK, pelayanan penggembalaan diuraikan berikut ini.

Rasul Paulus menyatakan: “...Ialah yang memberikan baik rasul-rasul maupun nabinabi, baik pemberita-pemberita Injil maupun gembala-gembala dan pengajar-pengajar." Nas ini meyakinkan bahwa Tuhan yang menetapkan pelayanan penggembalaan yang di dalamnya memiliki tanggung jawab seorang pemimpin sebagai manajer sekaligus pengajarpengajar dalam melaksanakan manajemen pendidikan (Ef. 4:11).

\section{Pelayanan Pastoral (Penggembalaan)}

Panggilan kasih kepada Tuhan (kasih agape) menjadi dasar panggilan dalam melayani murid-murid yang digembalakan. Oleh karena itu pengajaran PAK menjadi penting dalam pelayanan penggembalaan. Dalam Alkitab diceritakan kisah Petrus yang telah menyangkal tiga kali dikembalikan kepada posisi kepemimpinan karena dasar yang terutama adalah kasih. Kualitas yang diinginkan tetapi kasih adalah segalanya (Morris, 1999).
Tidball (1995) teologi pelayanan mengidentifikasikan penggembalaan sebagai cabang atau bidang pengetahuan dan penyelidikan teologis yang mengarahkan perspektif penggembalaan kepada semua tugas, kewajiban dan fungsi gereja dan gembala dalam bentuk teologis dari perenungan terhadap pengamatanpengamatan ini. Istilah itu didukung oleh sejumlah firman Tuhan yang intinya dimulai dan diakhiri oleh Allah sendiri. Anderson (1993) mendefinisikan penggembalaan sebagai tugas hamba Tuhan dalam memuridkan, melengkapinya, memelihara, memimpinnya, mengajarnya untuk melakukan kehendak Allah. Bons-storm (1993) mengatakan, Penggembalaan merupakan penerapan khusus Injil kepada anggota jemaat secara pribadi, yaitu berita Injil dalam khotbah gereja, disampaikan kepada semua orang. Pelayanan penggembalaan menerapkan suatu pekerjaan yang Tuhan Yesus pernah kerjakan di dunia ini dalam penggembalaan dan penginjilan, ini terdapat di dalam kitab Injil, dan berita ini harus disampaikan kepada setiap orang dan anggota gereja untuk mereka siap mendaji saksi Kristus.

Bons-storm (1993) berkata penggembalaan ialah tiap pekerjaan yang di dalamnya pelayan sadar akan akibat yang ditimbulkan oleh percakapan atau khotbahnya atas kepribadian orang yang saat dihubunginya. Perbandingan ketiga definisi di atas menekankan tugas pelayanan penggembalaan yang mengarah kepada tugas dan tujuan misi gereja dalam hubungan relasi antara gembala, pelayan dengan anggota-anggota jemaat.

Tidball (1995) menulis bahwa tugas penggembalaan ialah menolong orang satu per satu untuk menyadari hubungannya dengan Allah, dan mengajar orang untuk mengakui ketaatannya kepada Allah dan sesamanya, dalam situasi sendiri. Tugas pelayanan penggembalaan yang mengarah kepada tugas dan tujuan misi gereja dapat disebutkan sebagai berikut: Pertama, pelayanan penggembalaan pada jemaat. Kedua, pelayanan penggembalaan membangun jemaat untuk berbakti. Ketiga, pelayanan penggembalaan mencari orang sesat. Keempat, pelayanan penggembalaan memberitakan Firman. 
Kelima, pelayanan penggembalaan dalam menasihati, dan menegur.

Perkataan gembala dalam bahasa Yunani ialah poimen. Dalam bahasa latin, hal itu disebut pastor. Oleh karena itu penggembalaan dalam jemaat dapat disebut poimenika atau pastoralia. Pelayanan pastoral adalah pelayanan penggembalaan. Penggembalaan dalam jemaat secara praktis dapat dirumuskan sebagai berikut: Pertama, mencari, mengunjungi dan menghubungi anggota jemaat satu persatu. Kedua, mengabarkan firman Allah kepada mereka dalam situasi kehidupan mereka secara pribadi. Ketiga, melayani mereka seperti Yesus melayani mereka. Keempat, menegur dan menertibkan mereka yang menyimpang dan jalan yang benar. Kelima, mengajar mereka melalui teladan dengan kata-kata agar mereka melakukan kehendak Allah dalam kehidupan sehari-hari. Keenam, menolong mereka menyaksikan kabar keselamatan dalam Tuhan Yesus Kristus. Ketujuh, memperlengkapi mereka dengan kemampuan dan ketrampilan untuk melayani, menjadi dewasa, berapologet dan membangun tubuh Kristus (Bons-storm, 1993). Penggembalaan didasarkan pada kepemimpinan hamba (Pugar, 2016) kepemimpinan hamba berdasarkan pada tanggung jawab utama dalam pelayanan terhadap bawahan dengan meletakkan kepentingan bawahan di atas kepentingan pemimpin. Pelayanan penggembalaan bertujuan membawa anggota gereja dalam menghargai dan menerima sesamanya, maka komunitas ini sedang menunjukkan sifat relasional Allah dalam Trinitas (Linna, 2019, 70). Pelayanan penggembalaan diimplementasikan salah satunya ke dalam kelompok sel sebagai bagian pemuridan dan pengajaran PAK. Manajemen PAK melalui penggembalaan seperti diakonia, konseling dan penelaahan Alkitab di dalam kelompok sel dilakukan oleh mentor atau pemimpin kelompok sel.

\section{Kelompok Sel}

Prinsip Gereja Sel secara umum adalah gereja yang menjadikan sel segalanya dimana semua kegiatan dimodifikasi ke dalam bentuk sel. Contoh: Sekolah minggu dialihkan menjadi kelompok sel anak, pelayanan pemuda dijadikan kelompok sel pemuda, remaja, mahasiswa dll. Semakin kecil jumlah orang dalam setiap kelompok, pertumbuhan iman setiap anggota semakin mudah dibenahi (Comiskey, 1998). Pengertian prinsip kelompok sel adalah menyelenggarakan kelompok sel sebagai salah satu bagian dari kegiatan gereja dan bukan satu-satunya sistem yang diterapkan di dalam gereja seperti yang dilakukan oleh gereja sel yaitu persamaan dan perbedaan antara gereja sel dan kelompok sel, ibadah minggu dalam pola kelompok sel, pola kepemimpinan dalam gereja sel, pola kepemimpinan dalam kelompok sel.

Pelayanan penggembalaan yang menerapkan PAK membutuhkan beberapa metode mengajar dalam mengajar dan memuridkan dalam kelompok sel. Agung \& Astika (2011) mengemukakan beberapa metode mengajar Yesus yaitu ceramah, memberikan pertanyaan, perumpamaan, dan menggunakan alat peraga yang ada di sekitarnya. Pemimpin kelompok sel harus dapat menjadi manajer dalam mengelola kelompok sel supaya murid-muridnya dapat lebih aktif, dan menyenangkan. Pemimpin kelompok sel memberikan materi PAK sesuai pengajaran Yesus yang alkitabiah (Hana \& Weismann, 2020). Untuk lebih mengarahkan pada tujuan akhir kelompok sel maka pemimpin membuat kurikulum PAK dalam pelayanan penggembalaan. Sidjabat, (2019) mengungkapkan pengajaran PAK tidak hanya untuk mengajarkan iman Kristen, tetapi juga mengembangkan kepribadian dengan memfasilitasi terjadinya transformasi karakter.

Kelompok sel menjadi salah satu tempat pelayanan penggembalaan yang mengajarkan PAK secara teoritis (kognitif), tetapi juga mengamalkan hasil pemikiran yang dipahami ke dalam pelayanan penggembalaan. Kelompok sel adalah kelompok kecil yang merupakan bagian dari persekutuan yang lebih besar yang disebut dengan gereja. Dalam Alkitab nyata dikemukakan bahwa kelompok yang besar perlu dikelola dengan baik dengan cara menjadikan kelompok-kelompok lebih kecil. Seperti nasihat Yitro, mertua Nabi Musa. Hosea, (2018) berpendapat pola kepemimpinan dengan memakai kelompok kecil maka seorang pemimpin lebih efisien dalam menjalankan tugas pelayanannya (Kel. 18:18) 
dan pengajaran tentang kebenaran firman Tuhan dapat diterapkan dengan baik (Kel. 18:19-20).

Keuntungan murid-murid yang belajar dalam kelompok sel adalah salah satu tempat yang sangat baik untuk saling memerhatikan, saling mendoakan, saling berbagi kasih dan dapat mengembangkan karunia talenta masingmasing (Lubis, 2019). Selain itu ada prinsip pemuridan yaitu dimuridkan dan memuridkan. Mursanah, (2017) berpendapat bahwa setiap pemimpin kelompok sel akan membentuk para pemimpin lainnya yang akan menjadi asisten pemimpin dan akhirnya menjadi pemimpin kelompok sel lainnya.

Beberapa penelitian yang relevan dengan ide tulisan tentang PAK, pelayanan kelompok sel, yaitu: 1) Pengutamaan dimensi karakter dalam PAK (Nuhamara, 2018) yang menjelaskan karakter kristiani yang bersumber dari Alkitab yang diajarkan dalam PAK yang disertai dengan contoh tokoh-tokoh Alkitab; 2) Penelitian disertasi dengan jurnal Peer Tutor Learning Model in CRE-Based Discipleship Teaching According to Matthew 28:19-20 at High Schools in Makassar City, (Hana \& Weismann, 2020) yang memberikan kesimpulan pengajaran PAK berbasis pemuridan sesuai dengan Injil Matius 28: 19-20 sejalan dengan Amanat Agung, dengan demikian meningkatkan pelaksanaan Amanat Agung; 3) Penelitian kuantitatif dengan judul Pengaruh Kepribadian Big Five terhadap Gaya
Kepemimpinan Servant Leadership (Suatu studi pada pemimpin kelompok sel di Gereja Mawar Sharon Bandung), (Pugar, 2016) menyimpulkan kepribadian mempengaruhi gaya kepemimpinan servant leadership pada pemimpin kelompok sel di Gereja Mawar Sharon Bandung; 4) kelompok sel secara signifikan berpengaruh untuk pertumbuhan jemaat karena jemaat dimuridkan untuk memuridkan (Lubis, 2019, 5) Pengaruh kelompok sel terhadap pertumbuhan rohani (Padang \& Busthan, 2019) menyimpulkan kelompok sel merupakan kelompok kecil yang terdiri dari 812 untuk bertemu secara teratur sebagai sarana agar tiap anggota, dapat mempelajari firman Tuhan dan membagikan pengalaman hidup dalam suasana persaudaraan yang akrab dan menyenangkan untuk bertumbuh pada pengenalan akan Yesus Kristus.

\section{METODOLOGI}

Penelitian yang digunakan adalah penelitian kuantitatif dengan pengukuran Rating Scale (Sugiyono, 2014; Wijaya, 2016) pada setiap indikator pengukuran pelaksanaan PAK melalui pelayanan penggembalaan (Pastoral) dalam kelompok sel.

Populasi terdiri atas 115 anggota. Sampel atau responden yang mengisi kuesioner adalah 87 anggota jemaat GBI Graha Pena. Terdiri atas 35 responden laki-laki dan 52 responden perempuan. Sebaran responden berdasarkan kualifikasi pendidikan tampak pada Tabel 1.

Tabel 1. Responden berdasarkan kualifikasi pendidikan

\begin{tabular}{ccc}
\hline Jenjang pendidikan & Jumlah $(\mathrm{n})$ & Persentase $(\mathrm{n} / \mathrm{N}) * 100$ \\
\hline SD & 4 & 4,6 \\
SMP & 13 & 14,94 \\
SMU & 51 & 58,62 \\
S1 & 17 & 19,54 \\
S2 & 1 & 1,15 \\
S3 & 1 & 1,15 \\
Total & 87 & 100 \\
\hline
\end{tabular}

Anggota jemaat GBI Graha Pena masuk usia dewasa yang mengikuti kelompok sel sejak tahun 2003 hingga sekarang. Dengan demikian responden valid untuk menjawab kuesioner.

Analisis data kuantitatif diolah dari data primer yang bersumber dari kuesioner dan dibagi ke dalam indikator-indikator jenis pelayanan penggembalaan (pastoral) yang dilakukan di dalam kelompok sel. Selanjutnya dideskripsikan dengan argumentasi yang berkaitan dengan teori-teori manajemen PAK dan teologi pastoral. Skala pengukuran dimulai dari angka 1 hingga 5. Skala 1 (Tidak pernah); Skala 2 (jarang); Skala 3 (Kadang-kadang); 
Skala 4 (Sering); Skala 5 (Selalu). Hasil penilaian responden dianalisis dengan perhitungan Rating Scale (Sugiyono, 2014).

\section{HASIL DAN PEMBAHASAN}

Jumlah responden dalam penelitian ini adalah 87 responden yang aktif dalam kelompok sel. Peserta kelompok sel sudah mendapatkan pelayanan penggembalaan atau pastoral yang berisikan pengajaran PAK. Manajemen PAK dilaksanakan dengan memberikan pemahaman (pengetahuan) PAK melalui pelayanan pastoral, menerima pelayanan pastoral, dan melaksanakan pelayanan pastoral serta mengevaluasi pelayanan pastoral dalam kelompok sel dibandingkan bila dilakukan dalam kelompok yang lebih besar (gereja).

Respons responden terkait dengan kuesioner diolah menjadi pemahaman responden tentang manajemen PAK melalui pelayanan pastoral (diakonia, konseling Kristen, kunjungan orang sakit, kedukaan, pemberitaan kabar baik) yang dikelola oleh pemimpin gereja, pemimpin kelompok sel, dan anggota jemaat sebagai murid yang dimuridkan.

Tabel 2. Pemahaman arti dan makna manajemen PAK melalui pelayanan pastoral dalam kelompok sel

\begin{tabular}{lcccccc}
\hline \multicolumn{1}{c}{ Pernyataan kuesioner } & \multicolumn{3}{c}{ Skala } & & $\begin{array}{c}\text { Skala Likert } \\
(\%)\end{array}$ \\
\hline PAK dalam diakonia & 1 & 2 & 3 & 4 & 5 & 84,83 \\
Arti dan Tujuan PAK dalam Pelayanan pastoral & - & - & - & 66 & 21 & 8 \\
PAK dalam pelayanan doa & - & - & - & - & 87 & 100 \\
PAK dalam pelayanan Orang Sakit & - & - & - & 66 & 21 & 84,83 \\
PAK dalam Pelayanan Kedukaan & - & - & - & 65 & 22 & 85,06 \\
PAK dalam pelayanan konseling & - & - & - & 67 & 20 & 84,6 \\
Arti dan Tujuan PAK dalam Kelompok Sel & - & - & - & 65 & 22 & 85,06 \\
Rating Scale (\%) & - & - & - & 65 & 22 & 85,06 \\
& & & & 87,06 & \\
\hline
\end{tabular}

Analisis data kuantitatif dengan skala pengukuran Rating Scale $87,06 \%$ menunjukkan bahwa responden dalam memahami arti dan tujuan manajemen PAK melalui pelayanan pastoral dalam kelompok sel pada kategori sering. Dengan demikian responden memahami arti dan tujuan pelaksanaan manajemen PAK dalam pelayanan pastoral yang dilakukan di kelompok sel.
Pemahaman responden tentang arti dan tujuan PAK dalam pelayanan pastoral memengaruhi keterlibatan responden dalam kelompok sel. Pemimpin kelompok sel dapat mengoptimalkan pelayanan pastoral dalam kelompok sel. Namun pemahaman saja tidak cukup, tetapi membutuhkan keterlibatan aktif jemaat dalam kelompok sel supaya jemaat dapat memahami, tetapi juga dapat melaksanakan pelayanan itu sendiri.

Tabel 3. Dampak manajemen PAK dalam pelayanan pastoral bagi anggota kelompok sel

\begin{tabular}{lcccccc}
\hline \multicolumn{1}{c}{ Pernyataan kuesioner } & \multicolumn{3}{c}{ Skala } & & Skala Likert \\
& 1 & 2 & 3 & 4 & 5 & $(\%)$ \\
\hline Kebutuhan anggota akan pelayanan pastoral & - & - & 66 & 21 & - & 84,83 \\
Dampak Pelayanan Diakonia & - & - & 80 & 7 & - & 61,61 \\
Dampak Pelayanan doa & - & - & 67 & 20 & - & 64,6 \\
Pelayanan Kedukaan & - & - & 85 & 2 & - & 60,46 \\
Pelayanan konseling & - & - & 66 & 21 & - & 64,83 \\
Rating Scale (\%) & & & 67,26 & \\
\hline
\end{tabular}

Hasil pengukuran Rating Scale 67,26\% menunjukkan evaluasi pelayanan pastoral yang belum optimal. Pemimpin gereja dan pemimpin kelompok sel masuk dalam kategori kadang-kadang. Faktor yang menyebabkan hal itu terjadi karena tidak menindaklanjuti hasil 
pertemuan dalam kelompok sel. Pelayanan pastoral dalam kelompok kecil perlu dilakukan secara personal melalui komunikasi interpersonal yaitu melaksanakan pelayanan pastoral kepada setiap anggota baik yang membutuhkan dan yang tidak membutuhkan. Pemimpin kelompok sel proaktif berkomunikasi dan berbagi pendapat untuk meningkatkan pelayanan pastoral. Hasil penelitian Setyono (2013) menyimpulkan bahwa komunikasi interpersonal memengaruhi komitmen organisasi anggota kelompok sel. Dengan demikian pemimpin perlu blusukan ke rumah-rumah anggota jemaat untuk lebih mengetahui kebutuhan pelayanan pastoral. Pelayanan pastoral dalam kelompok sel tidak hanya untuk mengisi ranah kognitif, namun juga perlu bukti nyata implementasi pelayanan pastoral yang semakin optimal di lapangan pelayanan.

Tabel 4. Manajerial pelayan pastoral dalam kelompok sel

\begin{tabular}{lcccccc}
\hline \multicolumn{1}{c}{ Pernyataan kuesioner } & & \multicolumn{3}{c}{ Skala } & & Skala Likert \\
& 1 & 2 & 3 & 4 & 5 & $(\%)$ \\
\hline Kepemimpinan Pelayan pastoral berjalan dengan baik & - & - & 38 & 49 & - & 71,26 \\
Pengelolaan Pelayanan diakonia & - & - & 75 & 12 & - & 62,76 \\
Pengelolaan pelayanan doa & - & - & 75 & 12 & - & 62,76 \\
Pengelolaan pelayanan Orang Sakit & - & - & 15 & 72 & - & 76,55 \\
Pengelolaan Pelayanan Kedukaan & - & - & 82 & 5 & - & 61,15 \\
Pengelolaan pelayanan konseling & - & - & 72 & 15 & - & 63,45 \\
SDM pengelolaan pelayanan pastoral & - & - & 37 & 50 & - & 71,49 \\
Rating Scale (\%) & & & & 67,06 & \\
\hline
\end{tabular}

Data Rating Scale $67,06 \%$ pada kategori kadang-kadang. Artinya responden melihat pengelolaan pelayanan belum optimal dan perlu ditingkatkan. Sumber Daya Manusia sebagai pelayan pastoral menjadi hambatan pelayanan pastoral. SDM dalam hal cara memimpin kelompok sel perlu ditingkatkan melalui pelatihan seperti pelatihan kepemimpinan, pelatihan konselor, praktik pelayanan kedukaan, pelayanan doa, dan pelayanan pastoral kepada orang sakit. Untuk itulah pelayanan pastoral dalam kelompok sel perlu dikonkretkan di lapangan pelayanan supaya dapat dievaluasi dan ditingkatkan. Pengajaran PAK dalam pelayanan pastoral bersifat praktis dan alkitabiah sehingga pemimpin dan anggotanya dapat melakukan dengan baik dan benar.

Tabel 5. Keterlibatan Anggota dalam pelayanan pastoral di jemaat sebagai anggota kelompok sel

\begin{tabular}{lcccccc}
\hline \multirow{2}{*}{ Pernyataan kuesioner } & \multicolumn{9}{c}{ Skala } & \multicolumn{2}{c}{ Skala Likert (\%) } \\
& 1 & 2 & 3 & 4 & 5 & \\
\hline Pelayanan diakonia & 27 & - & 53 & 7 & - & 49,2 \\
Pelayanan orang sakit & - & - & 77 & 10 & - & 62,3 \\
Pelayanan doa & - & - & 67 & 20 & - & 64,6 \\
Pelayanan Kedukaan & - & - & 67 & 20 & - & 64,6 \\
Rating Scale (\%) & & \multicolumn{5}{c}{60,17} \\
\hline
\end{tabular}

Hasil Rating Scale 60,17\% menunjukkan rendahnya keterlibatan anggota kelompok sel dalam melaksanakan pelayanan pastoral kepada anggota jemaat. Bahkan ada 27 responden tidak pernah melakukan pelayanan diakonia. Pemimpin kelompok sel harus memotivasi anggotanya untuk melaksanakan pelayanan pastoral sebagai murid Kristus, dan melayani sesama anggota. Pemimpin memberikan dorongan dan teladan supaya anggota kelompok sel ikut terlibat dalam kegiatan pastoral dan tidak hanya mengikuti kegiatan kelompok sel tetapi belum menjadi murid. Kepemimpinan dan motivasi memengaruhi kinerja seseorang yang dipimpinnya (Banatau \& Wijaya, 2019; Saputra, 2020)

Pola manajemen PAK melalui pelayanan pastoral dalam kelompok sel, yaitu 1) Pengajaran PAK; 2) Melayani anggota melalui pendampingan pastoral dalam segala kegiatan 
pastoral; 3) Melibatkan secara aktif dalam kegiatan pastoral; 4) Memuridkan anggota kelompok sel melalui pelatihan dan mentoring; 5) Pelayanan pastoral yang lebih personal dalam keluarga anggota; 6) Belajar menjadi murid dan menjadi pemimpin kelompok sel; 7) Evaluasi dan menerima kritikan dan masukan untuk meningkatkan keterampilan dan pelayanan pastoral.

Temuan hasil penelitian menunjukkan pada tabel 2 pemahaman jemaat tentang arti dan makna tentang manajemen PAK melalui pelayanan penggembalaan menunjukkan hasil yang baik. Namun, pemahaman yang baik yang disertai dengan pelaksanaan yang optimal akan memberikan dampak yang tidak optimal. Hal tersebut terlihat pada tabel 3 dimana peran kepemimpinan dalam menerapkan manajemen Pendidikan menjadi penting. Manajemen Pendidikan tidak dapat dipisahkan dengan Pendidikan kepemimpinan (leadership education) (Grace \& Grace, 1995). Pemimpin yang baik tidak hanya memberi wawasan dan arahan kepada bawahannya tetapi juga menghasilkan pengikut yang dapat mengelola Pendidikan jemaat. Keberhasilan manajemen Pendidikan ditentukan oleh kepemimpinan gembala dalam mengarahkan sekaligus memimpin angota-anggotanya yang menjadi perwakilan pemimpin dalam kelompok seperti kelompok sel.

Untuk memberikan dampak optimal dalam pelayanan penggembalaan maka pemimpin dapat melakukan pelatihan untuk Pendidikan kepemimpinan dalam menerapkan manajemen Pendidikan dengan baik dan efektif. Harapan awal dalam penelitian ini bahwa manajemen Pendidikan dalam pelayanan penggembalaan (pastoral) memberikan dampak yang optimal bagi jemaat, namun jemaat justru memberikan jawaban sebaliknya. Jemaat yang bergabung dalam kelompok sel merespons rendah mengenai pelaksanaan manajemen Pendidikan melalui pelayanan pastoral. Hal itu terbukti dengan respons jemaat untuk terlibat dalam pelayanan pastoral yang rendah.

Pengajaran PAK dalam pelayanan pastoral tidak memberi pengaruh kepada jemaat dalam kelompok sel untuk terlibat dalam pelayanan pastoral. Ada beberapa hambatan yang dapat menyebabkan jemaat tidak terlibat yaitu ketidakhadiran di kelompok sel, tidak ada kewajiban untuk terlibat dalam pelayanan, rendahnya anjuran pemimpin kelompok sel untuk memotivasi jemaat untuk terlibat pelayanan, dan kesadaran jemaat melayani yang rendah.

Berdasarkan hasil penelitian ini maka dampak manajemen Pendidikan berpengaruh rendah dalam pelayanan pastoral. Dengan demikian dibutuhkan solusi untuk mengoptimalkan pelayanan penggembalaan dalam kelompok sel dengan tujuan akhir melibatkan jemaat dalam pelayanan pastoral. Makin banyak yang terlibat aktif dan dapat mengelola pelayanan maka makin banyak jemaat yang terlayani baik secara kuantitas dan kualitas. Dengan sendirinya pertumbuhan rohani dapat terwujud (Padang \& Busthan, 2019; Widiyanto \& Susanto, 2020).

Pembinaan warga jemaat dalam manajemen PAK dalam pelayanan pastoral dapat menjadi solusi untuk melibatkan jemaat dalam melayani dalam penggembalaan. Bukan hanya gembala yang melayani tetapi juga jemaat sebagai kesatuan gereja, dan pelayan Tuhan (Efesus 4:11).

\section{PENUTUP}

Manajemen Pendidikan Agama Kristen dalam pelayanan pastoral di Kelompok Sel dapat dipahami oleh anggota Kelompok Sel sebagai kebutuhan dalam pelayanan. Dampak pelayanan pastoral dalam Kelompok Sel adalah untuk melayani sesama dan pengabdian kepada Tuhan melalui keterlibatan anggota jemaat dalam pelayanan pastoral. Namun, perlu ditingkatkan dengan Pendidikan kepemimpinan untuk dapat melaksanakan manajemen Pendidikan secara optimal dalam pelayanan pastoral.

Kebutuhan anggota akan pelayanan pastoral menjadi prioritas untuk dikelola dengan baik dan Sumber Daya Manusia yang dilengkapi dengan Pendidikan kepemimpinan. Kepemimpinan dalam Kelompok Sel memengaruhi motivasi anggota Kelompok Sel untuk terlibat dalam pelayanan pastoral.

Pelaksanaan manajemen PAK perlu ditingkatkan dalam pelayanan pastoral dengan 
prinsip pemuridan untuk menjadi murid dan memuridkan dengan mengimplementasikan hasil yang diperoleh dalam Kelompok Sel baik itu pengetahuan, pengalaman, dan bukti nyata di lapangan.

Untuk peningkatan keterlibatan jemaat maka perlu dilakukan latihan manajemen Pendidikan dan Pendidikan kepemimpinan untuk jemaat yang bersedia melayani sesama melalui pelayanan pastoral. Keberhasilan pelayanan pastoral dipengaruhi kepemimpinan kelompok sel dalam melaksanakan manajemen Pendidikan, dan keterlibatan aktif jemaat untuk mendukung pemimpin melaksanakan pelayanan pastoral untuk tercapainya tujuan organisasi gereja.

\section{DAFTAR PUSTAKA}

Agung, I., \& Astika, M. (2011). Penerapan Metode Mengajar Yesus Menurut Injil Sinoptik Dalam Pelaksanaan Pendidikan Agama Kristen Di SMA Gamaliel Makassar. Jurnal Jaffray, 9(2), 147-171. https://doi.org/10.25278/jj71.v9i2.99

Anderson, R. C. (1993). The Effective Pastor. Moody Publishers.

Banatau, J. W., \& Wijaya, H. (2019). Pengaruh Gaya Kepemimpinan Kristen Pelayan Tuhan Terhadap Pencapaian Hasil Program Kerja Di GKII Jemaat Rhema Makassar. https://skripsi.sttjaffray.ac.id/index.php/s kripsi/article/view/15.

Başarı, G., Aktepebaşı, A., Yagci, E., \& Akdag, S. (2017). Postgraduate thesis assessment in educational management supervision and planning. Procedia Computer Science, 120, 887-892. https://doi.org/10.1016/j.procs.2017.11.3 22.

Bekker, C. J. (2009). Towards a Theoretical Model of Christian Leadership. Journal of Biblical Perspectives in Leadership, 2(2), 142-152.

Blackmore, J. (2006). Deconstructing Diversity Discourses in the Field of Educational Management and Leadership. Educational Management Administration \& Leadership, 34(2),
181-199.

https://doi.org/10.1177/17411432060624 92

Bons-storm, M. (1993). Apakah Penggembalaan itu? BPK Gunung Mulia.

Bush, T. (2002). Educational Management: Theory and Practice.

Channing, N. (2002). Anugerah dalam Pelayanan Penggembalaan. http://repository.seabs.ac.id/handle/1234 $56789 / 65$

Comiskey, J. (1998). Home Cell Group Explosion: How Your Small Group Can Grow and Mult. Touch Publications.

Fadhli, M. (2017). Manajemen Peningkatan Mutu Pendidikan. Tadbir: Jurnal Studi Manajemen Pendidikan, 1(2), 215-240. https://doi.org/10.29240/jsmp.v1i2.295

Grace, G. R., \& Grace, P. G. (1995). School Leadership: Beyond Education Management: an Essay in Policy Scholarship. Psychology Press.

Hana, S. R., \& Weismann, I. T. J. (2020). Peer Tutor Learning Model in CRE-Based Discipleship Teaching According to Matthew 28: 19-20 at High Schools in Makassar City. Jurnal Jaffray, 18(1), 73-94.

https://doi.org/10.25278/jj.v18i1.440.

Hasibuan, P. D., \& Bulan, S. E. (2019). Kepemimpinan dalam Gereja Katolik Paroki Ignatius Loyola dan Huria Kristen Batak Protestan Setiabudi menuju Persatuan. QUAERENS: Journal of Theology and Christianity Studies, l(2),

111-121. https://doi.org/10.46362/quaerens.v1i2.5

Hikmat, H. (2009). Manajemen Pendidikan. Pustaka Setia. http://digilib.uinsgd.ac.id/22419.

Hoff, K. E., \& DuPaul, G. J. (1998). Reducing Disruptive Behavior in General Education Classrooms: The Use of SelfManagement Strategies. School Psychology Review, 27(2), 290-303. https://doi.org/10.1080/02796015.1998.1 2085916 
Hosea, A. (2018). Fenomena Kelompok Sel (Cell Group) Dalam Gereja Lokal. Diegesis: Jurnal Teologi, 3(2), 1-11.

Juld, R. J., \& Enoh, I. K. (2013). Okultisme Dalam Pelayanan Pastoral. Jurnal Jaffray, 11(2), 165-190. https://doi.org/10.25278/jj71.v11i2.83

Kleber, C., Giesecke, M. T., Tsokos, M., Haas, N. P., \& Buschmann, C. T. (2013). Trauma-related Preventable Deaths in Berlin 2010: Need to Change Prehospital Management Strategies and Trauma Management Education. World Journal of Surgery, 37(5), 1154-1161. https://doi.org/10.1007/s00268-0131964-2

Kusuma, I. H. (2006). Manajemen Pendidikan di Era Reformasi. Jurnal Pendidikan Penabur, 5(6), 76-86.

Lubis, B. (2019). Pengaruh Kelompok Sel Terhadap Pertumbuhan Jemaat di Gereja Perhimpunan Injili Baptis Indonesia. Jurnal Pionir, 5(3), 1-5. https://doi.org/10.36294/pionir.v5i3.726

Morris, L. (1999). Teologi Perjanjian Baru. Gandum Mas.

Muhaimin. (2015). Manajemen Pendidikan (Aplikasinya dalam Penyusunan Rencana Pengembangan Sekolah/ Madrasah). Prenada Media.

Mursanah. (2017). Peran kelompok Sel Yonggi Cho dalam perkembangan gereja pantekosta di Korea Selatan [UIN Syarif Hidayatullah].

http://repository.uinjkt.ac.id/dspace/hand le/123456789/37755

Nainggolan, M. M. (2019). Manajemen Pendidikan Agama Kristen (PAK) di Gereja Kristen Indonesia (GKI) Camar, Jaka Mulya Bekasi. Jurnal Teologi Rahmat, 5(1), 96-117.

Nuhamara, D. (2018). Pengutamaan Dimensi Karakter Dalam Pendidikan Agama Kristen. Jurnal Jaffray, 16(1), 93-114. https://doi.org/10.25278/jj71.v16i1.278

Padang, S. M., \& Busthan, P. (2019). Kajian Kelompok Sel Terhadap Pertumbuhan Rohani Pemuda Di Gereja Kemah Injil
Indonesia Mazmur Termindung Samarinda. Repository Skripsi Online, 1(1), 62-67.

Patandean, Y. E., \& Hermanto, B. W. (2019). Tema-Tema Theologis Khotbah Yesus Di Bukit Dalam Injil Matius 5:1-7:29. Evangelikal: Jurnal Teologi Injili Dan Pembinaan Warga Jemaat, 3(2), 123135.

Pugar, D. H. (2016). Pengaruh Kepribadian Big Five terhadap Gaya Kepemimpinan Servant Leadership (Suatu Studi pada Pemimpin Kelompok Sel di Gereja Mawar Sharon Bandung) [Universitas Kristen Maranatha]. http://repository.maranatha.edu/19939/10 /1130039_References.pdf

Ronda, D. (2011). Leadership Wisdom. Kalam Hidup.

Ronda, D. (2013). Dasar Teologi yang Teguh: Panduan Teologi Sistematika Di Perguruan Tinggi. Sekolah Tinggi Theologia Jaffray Makassar.

Saputra, Y. N. (2020). Pengaruh Kepemimpinan, Motivasi, dan Kompensasi Terhadap Kinerja Dosen. EDUKASI: Jurnal Penelitian Pendidikan Agama Dan Keagamaan, 18(1). https://doi.org/10.32729/edukasi.v18i1.6 03

Setyono, F. (2013). Pengaruh Kualitas Komunikasi Interpersonal Pemimpin Kelompok Sel Terhadap Komitmen Organisasi Anggota Kelompok Sel di Satelit Holy Gereja Mawar Sharon Surabaya. Jurnal E-Komunikasi, 1(2), 190-199.

Sidjabat, B. S. (2019). Kerangka Kurikulum Pendidikan Agama Kristen Berbasis Karakter di Perguruan Tinggi. Jurnal Jaffray, 17(1), 73-90. https://doi.org/10.25278/jj71.v17i1.314

Sinlae, R. Y. (2019). Kompetensi Pedagogik Tuhan Yesus dalam Injil Matius Pasal 57. Excelsis Deo: Jurnal Teologi, Misiologi, dan Pendidikan, 4(1), 35-55.

Stott, J. R. W. (1999). Khotbah Di Bukit. Yayasan Komunikasi Bina Kasih/OMF. 
Sugiyono. (2014). Metode Penelitian Pendidikan Pendekatan Kuantitatif, Kualitatif, dan $R \& D$. Alfabeta.

Tidball, D. J. (1995). Teologi penggembalaan: Sebuah pengantar. Gandum Mas.

Widiyanto, M. A., \& Susanto, S. (2020). Pengaruh Pelayanan Kunjungan Pastoral Terhadap Pertumbuhan Rohani Jemaat. Evangelikal: Jurnal Teologi Injili Dan Pembinaan Warga Jemaat, 4(1), 39-46. https://doi.org/10.46445/ejti.v4i1.214
Wijaya, H. (2016). Metodologi Penelitian Pendidikan Teologi. Sekolah Tinggi Theologia Jaffray Makassar.

Wijaya, H., \& Harimisa, Y. (2015). Spiritualitas Kerajaan Allah: Khotbah Yesus di Bukit dan Implikasinya bagi Kehidupan Kristen. https://repository.sttjaffray.ac.id/publicati ons/269449/spiritualitas-kerajaan-allahkhotbah-yesus-di-bukit-danimplikasinya-bagi-kehidupan 